\title{
Optical Microscopy-Guided Laser Ablation Electrospray Ionization Ion Mobility Mass Spectrometry: Ambient Single Cell Metabolomics with Increased Confidence in Molecular Identification
}

\author{
Michael J. Taylor ${ }^{1} \mathbb{D}$, Sara Mattson ${ }^{2}$, Andrey Liyu ${ }^{1}$, Sylwia A. Stopka ${ }^{2,3}$ (D) Yehia M. Ibrahim ${ }^{1}\left(\mathbb{D}\right.$, Akos Vertes $^{2} \mathbb{D}$ \\ and Christopher R. Anderton 1,*(D) \\ 1 Earth and Biological Sciences Directorate, Pacific Northwest National Laboratory, Richland, WA 99352, USA; \\ michael.taylor@pnnl.gov (M.J.T.); Andrey.Liyu@pnnl.gov (A.L.); Yehia.Ibrahim@pnnl.gov (Y.M.I.) \\ 2 Department of Chemistry, The George Washington University, Washington, DC 20052, USA; \\ smattson006@gwmail.gwu.edu (S.M.); sstopka@bwh.harvard.edu (S.A.S.); vertes@gwu.edu (A.V.) \\ 3 Department of Neurosurgery, Brigham and Women's Hospital, Harvard Medical School, \\ Boston, MA 02115, USA \\ * Correspondence: christopher.anderton@pnnl.gov; Tel.: +1-509-371-7970
}

Citation: Taylor, M.J.; Mattson, S.; Liyu, A.; Stopka, S.A.; Ibrahim, Y.M.; Vertes, A.; Anderton, C.R. Optical Microscopy-Guided Laser Ablation Electrospray Ionization Ion Mobility Mass Spectrometry: Ambient Single Cell Metabolomics with Increased Confidence in Molecular Identification. Metabolites 2021, 11, 200. https://doi.org/10.3390/ metabo11040200

Academic Editors: Troy D. Wood, Touradj Solouki and Kermit K. Murray

Received: 26 February 2021

Accepted: 25 March 2021

Published: 27 March 2021

Publisher's Note: MDPI stays neutral with regard to jurisdictional claims in published maps and institutional affiliations.

Copyright: (c) 2021 by the authors. Licensee MDPI, Basel, Switzerland. This article is an open access article distributed under the terms and conditions of the Creative Commons Attribution (CC BY) license (https:/ / creativecommons.org/licenses/by/ $4.0 /)$.

\begin{abstract}
Single cell analysis is a field of increasing interest as new tools are continually being developed to understand intercellular differences within large cell populations. Laser-ablation electrospray ionization mass spectrometry (LAESI-MS) is an emerging technique for single cell metabolomics. Over the years, it has been validated that this ionization technique is advantageous for probing the molecular content of individual cells in situ. Here, we report the integration of a microscope into the optical train of the LAESI source to allow for visually informed ambient in situ single cell analysis. Additionally, we have coupled this 'LAESI microscope' to a drift-tube ion mobility mass spectrometer to enable separation of isobaric species and allow for the determination of ion collision cross sections in conjunction with accurate mass measurements. This combined information helps provide higher confidence for structural assignment of molecules ablated from single cells. Here, we show that this system enables the analysis of the metabolite content of Allium cepa epidermal cells with high confidence structural identification together with their spatial locations within a tissue.
\end{abstract}

Keywords: mass spectrometry; collisional cross section; drift tube ion mobility separation; laser ablation electrospray ionization; in situ metabolomics; ambient analysis

\section{Introduction}

Molecular differences between isogenic cells occur as each cell has a unique biochemistry based on its transcript, protein, and metabolite profiles in addition to environmental perturbations [1]. Isogenic cells within tissues contain a diverse population of molecules including proteins, lipids, and metabolites, many of which may vary in their composition and concentration in response to environmental and biochemical factors [2]. Oxidative stress [3], random mutations [4], and gene fluctuations [5] can all introduce molecular profile differences between cells of the same genotype. Tissues can therefore be considered as mixtures of cells with possible subpopulations present within individual cell genotypes [6,7]. Single cell analysis is therefore vital to understand the complete biotic state of an organism given the fact that bulk analysis provides a weighted data average which obscures any cell-to-cell variance [2]. For this reason, there is increasing interest in developing tools able to characterize molecular composition on a single cell scale [2].

Mass spectrometry (MS) has become a core tool for single cell metabolomics over the last few decades [2]. This is in part due to the development of analytical probes (e.g., 
ion beams, lasers, and solvent junctions) capable of measuring at spatial resolutions enabling biochemical characterization at the cell level [2,8-10]. Additionally, instrumentation developments have expanded the detection limit for poorly ionizable and low abundant molecules providing the ability to measure sub-attomolar metabolite concentrations within individual cells [2]. For these reasons, MS is increasingly used for single cell analysis [2]. However, many MS-based methods require sample configurations, sample preparations, and analysis conditions that elicit structural and chemical changes within the cell [11,12], most prominently redistribution of labile biomolecules which include certain metabolites [13]. There are numerous examples documenting the effect of sample environment and preparation on changes in metabolite distributions within tissues across MS techniques (e.g., matrix-assisted laser desorption/ionization) [14,15]. For this reason, in situ methods, capable of native state sampling, are increasingly sought after for metabolomics.

Laser-ablation electrospray ionization mass spectrometry (LAESI-MS) is an emerging technique for in situ metabolomics that relies on mid-infrared laser irradiation (i.e., $\lambda=2940 \mathrm{~nm}$ ) to probe water-rich samples. LAESI-MS requires little to no sample preparation, and therefore many biological samples can be analyzed in their native state. For this reason, LAESI-MS has been applied for metabolomics in a variety of organisms [16-18], and in particular, plant systems due to the availability of endogenous water within plant cells [19]. LAESI-MS operates by directing a mid-IR laser to the sample to stimulate ablation of molecules in situ, which can be performed using several sampling configurations [2]. However, fiber-based LAESI-MS (f-LAESI-MS), where the laser is guided to the sample surface via an etched optical fiber, has shown the most progress for single cell analysis [20-22]. f-LAESI-MS single cell studies have included microdissection for intracellular analysis [22] and identification of heterogenous cell populations [23]. However, a major limitation of ambient analysis methods, which includes LAESI-MS, is the potential for a high background interference from the surrounding environment and spectral complexity due to the lack of orthogonal separation [24]. To circumvent these challenges, high mass resolution MS has been implemented with f-LAESI-MS [23]. f-LAESI-MS combined with ultrahigh magnetic field strength Fourier transform ion cyclotron resonance (FTICR)-MS has previously been demonstrated for sensitive, high mass accuracy metabolomic applications [20]. Using this technique, isotopic fine structure patterns were resolved allowing for increased accuracy of molecular annotations within infected soybean root nodules cells [20]. However, FTICR-MS is unable to resolve isomeric species, and usually requires additional orthogonal molecular analyses (e.g., tandem MS) to annotate the detected species, which can increase analytical timescales considerably $[25,26]$. Accordingly, methods for rapid single cell LAESI-MS are needed.

Ion mobility separation (IMS) provides an alternative to chromatographic separation as ions can be separated according to their electrophoretic mobility in an inert carrier gas (e.g., argon, nitrogen). This method circumvents the need for lengthy chromatographic separation steps to resolve isotopologues, and is therefore is ideal for high-throughput analysis [27]. However, the most valuable aspect of IMS is the ability to measure ion neutral collision cross sections (CCS) which offers an additional orthogonal dimension that can provide higher annotation confidence in replace of tandem MS analyses [27]. Accordingly, IMS has been implemented with various ambient ionization methods in biological studies [28]. However, to this date, there have been minimal studies reporting the combination of IMS with LAESI-MS for biological studies [18,27,29-32]. Recent applications of LAESI-IMS-MS include investigating biological nitrogen fixation processes resulting from the symbiotic relationship between soil rhizobia and infected soybean root nodules [18], and coupling of a home built mid-infrared-matrix assisted laser desorption electrospray ionization (IRMALDESI) source to a commercially available drift-tube ion mobility mass spectrometer (DTIMS) for intact protein imaging in Quercus Alba (oak leaf) [27].

As stated, LAESI-MS utilizes endogenous water to facilitate molecular ablation, and therefore in single cell applications, requires the IR laser probe to sample at individual cell centers with sub-cellular spot sizes [2]. For this reason, instruments combining optical 
microscopy with an ionization source for in situ analysis are particularly useful in this context, as optical selection of individual cells can be performed followed by MS analysis $[2,33]$. Additionally, dual-microscopy/MS instruments are attractive as they provide structural and chemical information from samples allowing for correlation of ion distributions with topographical features [34]. In this study, we developed a bimodal imaging system integrating a single optical train to accommodate both brightfield illumination and molecular imaging with ion mobility separation of cells in their native state within tissues (Figure 1). The use of a reflective objective in this source enables the visualization of individual cells and their targeting for LAESI-MS analysis. This LAESI-MS configuration is amenable for high-throughput single cell sampling through software automation by determining cell centroid coordinates which can be captured by the microscope software enabling sequential cell-by-cell analysis directly from tissues. Coupling this source to a DTIMS enabled ${ }^{\mathrm{DT}} \mathrm{CCS}$ values to be directly measured and cross compared against reference values from metabolite libraries allowing for higher confidence in the assignment of molecular structures from individual cells [35]. In this article, we detail the design of this "LAESI microscope," describe the workflow for single cell analysis, demonstrate the sensitivity of our system for detection of verapamil, and finally characterize metabolites with direct ${ }^{\mathrm{DT}} \mathrm{CCS}$ measurement from 60 single $A$. Cepa. epidermal cells.

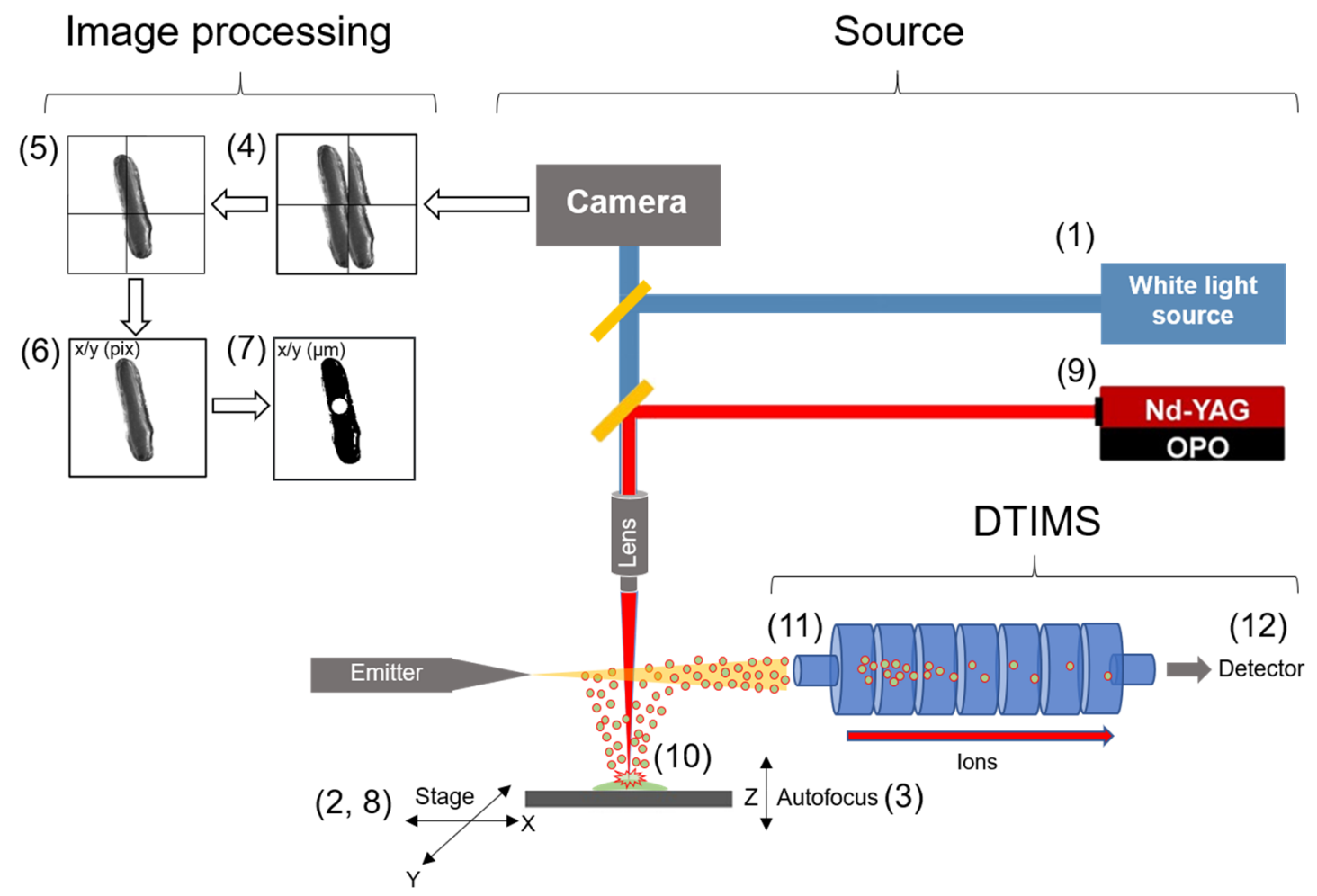

Figure 1. Schematic of LAESI-DTIMS based microscope system and its use. (1) A white light source is directed to the sample surface. (2) The Peltier-cooled stage moves to a sample position. (3) The microscope software performs autofocusing at the sample position by fine adjustment of the stage in the $Z$ axis and records an image, then the stage moves in $X / Y$ to an adjacent area to collect an image array with a specified number of tiles. (4) Image tiles are aligned. (5) Image tiles are overlapped and stitched together. (6) image coordinates (pixels) are converted to stage coordinates ( $\mu \mathrm{m})$ using a home built LabView software. (7) Cell center coordinates (X/Y $\mu \mathrm{m})$ are extracted, and a list of cell centers coordinates are entered into the LAESI-MS microscope software. (8) The stage moves sequentially to each cell centroid coordinate. (9) When the stage arrives at a cell centroid the MS sends a trigger to the laser to fire upon the ion trap opening. (10) The ion trap opens, the targeted cell is ablated, and endogenous molecules are intercepted by the electrospray and directed into MS inlet. (11) Ion packets are accumulated in the quadrupole trap and injected into DTIMS. (12) Ions are separated in the gas phase according to electrophoretic mobility and mass over charge of each ion is recorded by the TOF-MS. 


\section{Results and Discussion}

\subsection{Optimization of the Molecular Microscope Sampling Modality}

To optimize and determine the sensitivity of the DTIMS component of the LAESI microscope, droplets of verapamil were ablated at various concentrations (Figure S1) [36]. Droplets were analyzed by timing the laser firing with the ion accumulation of the DTIMS (MS triggered) and by freely firing the laser independent of the DTIMS (non-triggered). An optical image of a droplet of verapamil solution using the microscope component and an example spectrum using LAESI-DTIMS can be seen in Figure S1a,b, respectively. A ${ }^{\mathrm{DT}} \mathrm{CCS}$ $\left(\AA^{2}\right)$ of $209.3 \AA^{2} \pm 0.8$ was determined for verapamil which is in good agreement $(0.3 \%$ error) with published values $\left(210.0 \AA^{2} \pm 1.1\right)$ [37]. A series of verapamil concentrations were then analyzed in both MS-triggered and non-triggered modes to determine the effect of triggering on sensitivity (Figure S1c). Timing the laser to fire with the ion accumulation of the DTIMS resulted in a better sensitivity and a lower signal variability across the series of verapamil concentrations $\left(1.0 \times 10^{-3}-1.0 \times 10^{-7} \mathrm{~mol} / \mathrm{L}\right)$. Conversion of abundance to signal-to-noise ratio was performed to determine the limit of detection (LOD) for both modes (Figure S1d). Based on the LOD measurements, the MS-triggered mode is more sensitive than non-triggered mode ( $32 \mathrm{fmol}$ vs. $7460 \mathrm{fmol}$ ). This is unsurprising as continuously pulsing the laser (non-triggered) will vary the ion yield per accumulation period, decreasing sensitivity and increasing signal variance, as noted before $[25,38]$. The recorded sensitivity is however lower than we have previously reported on other MS systems, where $10 \mathrm{fmol}$ and $8 \mathrm{fmol}$ were measured on the 21 Tesla FTICR-MS and Waters Synapt G2Si (without ion mobility active), respectively $[25,39]$. This decrease in sensitivity can be explained by ion losses at the DTIMS interface reducing ion transfer efficiency [40-43].

Understanding the technical noise associated with our system was imperative to accurately measure metabolic noise across a cell population $[20,23]$. To determine the technical noise of our system $\left(\eta_{\text {techt }}{ }^{2}\right)$, verapamil droplets $\left(3 \mu \mathrm{L}\right.$ of $\left.1.0 \times 10^{-3} \mathrm{~mol} / \mathrm{L}\right)$ deposited on parafilm coated slides were analyzed in both MS-triggered and non-triggered mode (Figure S2a,b). Technical noise is defined as $\eta_{\text {tech }}{ }^{2}={ }_{\sigma \text { tech }}{ }^{2} / \mu$ tech ${ }^{2}$ where ${ }_{\sigma \text { tech }}{ }^{2}$ is the standard deviation of the recorded abundance across the technical replicates, and $\mu$ tech ${ }^{2}$ is the mean abundance. Our results demonstrated that synchronizing the laser firing with the ion accumulation of the DTIMS nearly reduced the technical noise of the system by half. Specifically, MS-triggered, and non-triggered mode resulted in a technical noise level of 0.380 and 0.603 , respectively. Analysis of maltose solution droplets using MS-triggered mode was also performed which resulted in a noise level equivalent to that of verapamil droplets analyzed under the same conditions $\left(\eta_{\text {tech }}{ }^{2}=0.361\right)$.

\subsection{Configuration of the Optical Train for Single Cell Identification and Ablation}

Laser alignment paper was used to optimize the laser focus and uniformity with respect to the sample distance to the plane of electrospray tip and MS capillary inlet by firing one laser shot across a range of $Z$ heights (Figures S3 and S4). The optical train was then configured to perform autofocusing and large area imaging to enable at focus imaging of tissue sections larger than the diameter of the objective field of view. Incorporating a dual use reflective objective for microscopy and laser ablation allowed for simultaneous optical microscopy and LAESI-DTIMS analysis to be performed within the same optical plane without switching between objectives. Additionally, the integration of image stitching software into the system enabled control of the sample stage for sample scanning, imaging, and feature-based image recognition to recombine individual tiles into a large image and to compensate for factors such as the orientation of the sample on the stage (Figure 2). A chip with regular microwell features was used to optimize this workflow by collecting overlapping image tiles ( $30 \mu \mathrm{m}$ overlap) that were intentionally misaligned in the $\mathrm{Y}$ axis by $100 \mu \mathrm{m}$ (Figure 2a,b). To test the robustness of the imaging workflow, no removal of vignetting was performed on individual image tiles, as correction of vignetting increases the feature intensity at the image periphery, which improves feature based stitching [44]. This workflow was effective to compensate for image misalignment 
and vignetting. Recombination of separate images taken from the microwell chip based on feature recognition into a stitched $5 \times 2$ array is shown in Figure 2c. This workflow was then tested on single cell epidermal tissue layers of $A$. Cepa. with vignetting removal (Figure $2 \mathrm{~d}$ ) which was shown to be effective for recombining image tiles from more challenging and structurally complex A. Cepa tissue (Figure $2 \mathrm{~d}$ ) and was scalable to larger image arrays (e.g., tested up to a $2 \times 6$ array of $490 \times 490 \mu \mathrm{m}$ image tiles from $A$. Cepa tissue, as seen in Figure S5). Using the home-built calculator in our modified LabView (2019) software, pixel coordinates from the center of $A$. Cepa cells were converted to stage coordinates (Figure 2e) for LAESI-DTIMS analysis. Figure $2 \mathrm{f}$ shows an image of an $A$. Cepa epidermal cell following laser ablation, as evidence that ablation can be directed at individual cells.

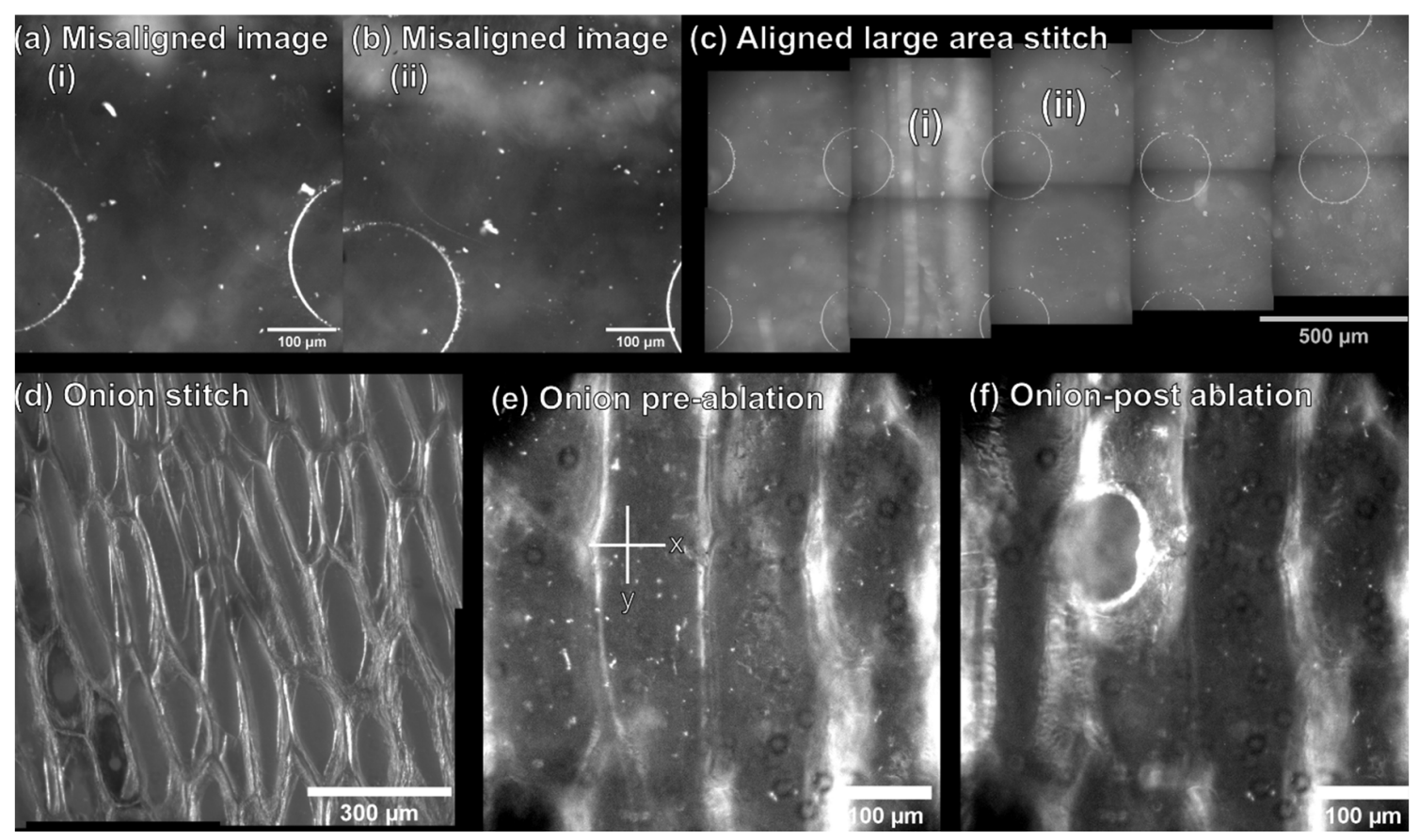

Figure 2. Optimizing the optical microscopy component for feature-based image stitching and single cell identification. (a,b) Separate image tiles from a microwell chip with vertical misalignment (100 $\mu \mathrm{m})$, where (c) the misaligned tiles (i) and (ii) are recombined into an aligned stitched mosaic image based on feature recognition. (d) Image tiles from $A$. Cepa tissue are aligned and stitched together into a $2 \times 2$ stitched mosaic image. (e) An individual $A$. Cepa. epidermal cell prior to laser ablation, cell coordinates are extracted as stage coordinates $(X, Y ; \mu \mathrm{m}, \mu \mathrm{m})$, and (f) the same single cell after LAESI-DTIMS sampling.

\subsection{LAESI-DTIMS Analysis of Single A. Cepa Epidermal Cells}

LAESI-DTIMS analysis of a single A. Cepa epidermal cell is shown in Figure 3. The mobiligram (Figure 3c) combines a single cell spectrum (Figure 3a) with ion mobility (Figure $3 \mathrm{~b}$ ) as a visual representation of $m / z$ versus mobility. Within the mobiligram in Figure 3c, several species can be observed in green/yellow against the electrospray background (blue). The most pronounced peaks in the corresponding overall spectrum (Figure 3a) include $m / z$ 272.127, $m / z$ 365.105, $m / z$ 381.080, $m / z$ 543.131, and $m / z$ 705.182. We observed that these species corresponded to different monosaccharide and polysaccharide adducts based on their accurate mass measurements. These assignments are displayed in Table 1. Figure $3 \mathrm{~d}$ displays a constrained region on the mobiligram area around the tentatively assigned trisaccharide at $m / z$ 543.131. A study by Shrestha et al. also observed this species $m / z 543.132$ in A. Cepa, assigned to a unspecified potassiated trisaccharide [21]. $\mathrm{C}_{18}$ sugars present in A. Cepa include cellotriose, melezitose, isomaltotriose, ketose, maltotriose, and raffinose, which are indistinguishable by mass measurements alone, as they are structural isomers. To identify the specific trisaccharide in this list of isotopologues, 
we measured the ${ }^{\mathrm{DT}} \mathrm{CCS}$ for this peak, determining a value of $217.26 \AA^{2}$. Comparing this value against ${ }^{\mathrm{DT}} \mathrm{CCS}$ values published in a metabolite database on a DTIMS system [35] indicates that this species is likely cellotriose. Additionally, $m / z 527.158$ was identified as the sodiated adduct of cellotriose, as the ${ }^{\mathrm{DT}} \mathrm{CCS}$ value $\left(215.94 \AA^{2}\right)$ was in good agreement with database values $(0.37 \%$ error; $216.69 \pm 0.21)$ [35]. Observation of cellotriose a major species in A. Cepa is expected as cellulose is the major component of the cell wall and the predominant polysaccharide in the skins of onion [45]. These results illustrate the value of ion mobility for more confident structural assignments. Ion mobility provides an additional dimension to identify a specific trisaccharide from several possible trisaccharides. All further species putatively identified within the single $A$. Cepa epidermal cell are listed in Table 1, which include additional saccharides, secondary metabolites (e.g., indigotin, caranine, and quercetin), and flavonoids (e.g., alliin, erosone, and davidioside).

(c) A. Cepa mobiligram

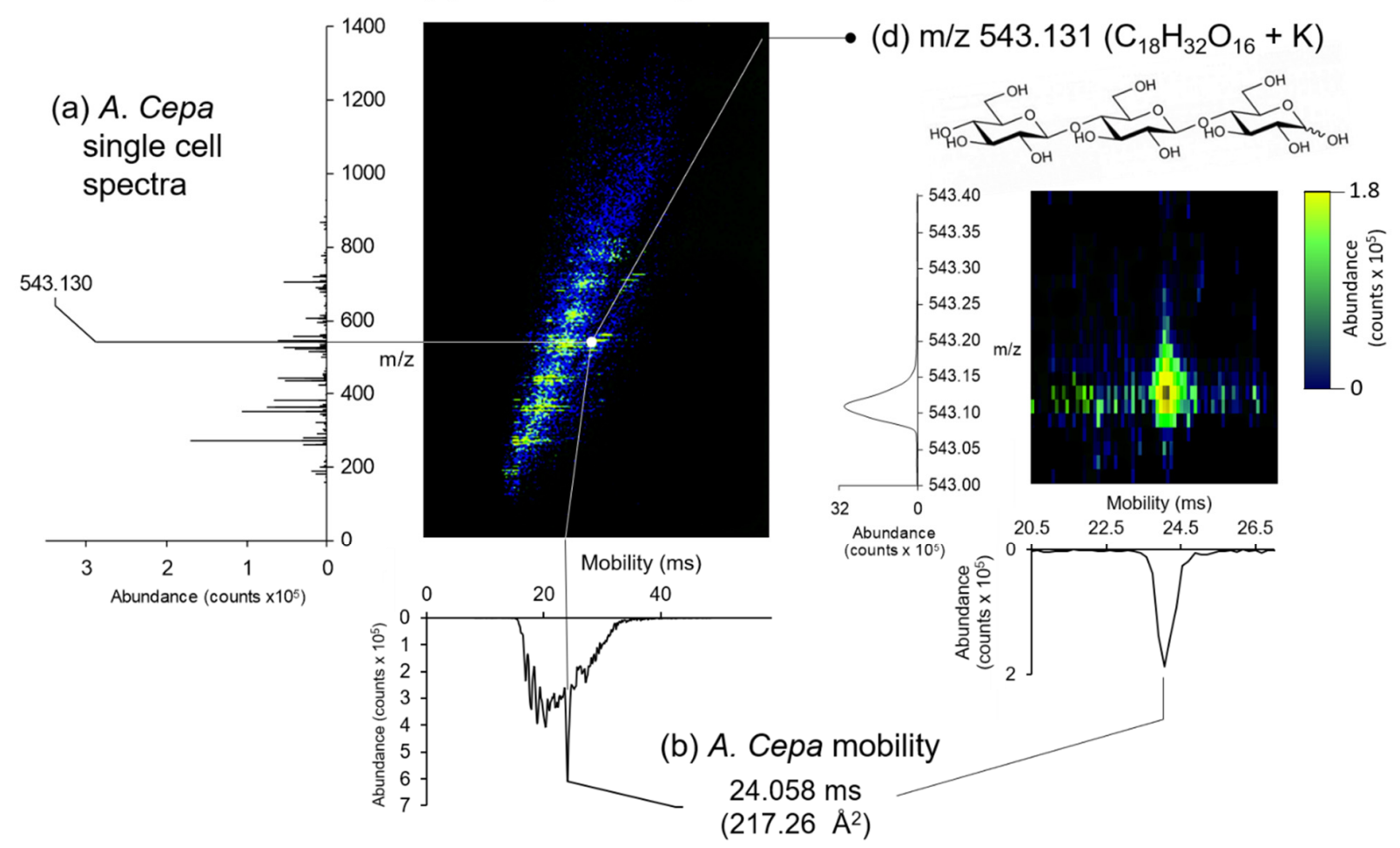

Figure 3. Example LAESI-DTIMS analysis of a single A. Cepa cell. (a) Spectrum with the saccharide peak labeled, (b) the corresponding mobility graph, and the (c) mobiligram showing detected species (green/yellow). (d) Spectrum and mobility graph of $m / z 543.131\left(\mathrm{C}_{18} \mathrm{H}_{32} \mathrm{O}_{16}+\mathrm{K}\right.$, Trisaccharide) with corresponding mobiligram.

\subsection{Mobility Separation of Isomeric Species in Single A. Cepa Epidermal Cells}

DTIMS systems have the capability to resolve structural isomers, as has been well established in previous studies [46]. We observed mobility separation of two species at mass $m / z 272.124$ (Figure 4) with respective ${ }^{\mathrm{DT}} \mathrm{CCSs}$ of $144.22 \AA^{2}$ and $153.61 \AA^{2}$. Shrestha et al. observed this peak in a prior study assigning it as caranine, crinine, or vittatine based on exact mass [21]. Vittatine and crinine are stereoisomers, whereas caranine is a structural isomer of vittatine and crinine, it is therefore likely that mobility separation is based on the two isomeric conformations. However, additional experiments for these metabolites are required for structural confirmation because no ${ }^{\mathrm{DT}} \mathrm{CCS}$ values are currently available in public databases [35,47]. Mobility resolution for these species was calculated $\mathrm{R}=64.36$. Our DTIMS instrument demonstrated higher mobility resolution power in comparison to our previous work on the TWIMS-based Waters Synapt G2S, which has demonstrated resolutions of $\mathrm{R} \leq \sim 60[18,48-50]$. 
Table 1. Putative molecular assignments from LAESI-DTIMS analysis of single A. Cepa epidermal cells.

\begin{tabular}{|c|c|c|c|c|c|}
\hline Species & Structure & $\begin{array}{l}\text { Observed Mass } \\
\qquad(\mathrm{m} / \mathrm{z})\end{array}$ & $\begin{array}{c}\text { Expected Mass } \\
(\mathrm{m} / \mathrm{z})\end{array}$ & Deviation (ppm) & ${ }^{\mathrm{DT}} \operatorname{CCS}\left(\AA^{2}\right)$ \\
\hline Tyrosine $1,3,5$ & $\mathrm{C}_{9} \mathrm{H}_{11} \mathrm{NO}_{3}+\mathrm{H}$ & 182.082 & 182.082 & 0.204 & (II) 146.42 \\
\hline Alliin ${ }^{3,4}$ & $\mathrm{C}_{6} \mathrm{H}_{11} \mathrm{NO}_{3} \mathrm{~S}+\mathrm{Na}$ & 200.035 & 200.035 & 1.724 & 144.15 \\
\hline Lauric acid 2,5 & $\mathrm{C}_{12} \mathrm{H}_{24} \mathrm{O}_{2}+\mathrm{H}$ & 201.184 & 201.184 & 1.827 & 154.01 \\
\hline Monosaccharide $1,2,5$ & $\mathrm{C}_{6} \mathrm{H}_{12} \mathrm{O}_{6}+\mathrm{K}$ & 219.026 & 219.026 & 2.077 & 146.42 \\
\hline Major (unknown) & $\mathrm{n} / \mathrm{a}$ & 261.144 & $\mathrm{n} / \mathrm{a}$ & $\mathrm{n} / \mathrm{a}$ & 144.15 \\
\hline Indigotin 6 & $\mathrm{C}_{16} \mathrm{H}_{10} \mathrm{~N}_{2} \mathrm{O}_{2}+\mathrm{H}$ & 263.084 & 263.082 & 7.760 & 145.43 \\
\hline $\mathrm{Cri} /(\mathrm{Ca} / \mathrm{Vi})^{1,6}$ & $\mathrm{C}_{16} \mathrm{H}_{17} \mathrm{NO}_{3}+\mathrm{H}$ & 272.127 & 272.128 & -4.900 & $(144.22 / 153.61)$ \\
\hline Glut/cystox 6 & $\mathrm{C}_{9} \mathrm{H}_{16} \mathrm{~N}_{2} \mathrm{O}_{6} \mathrm{~S}+\mathrm{H}$ & 281.089 & 281.089 & -1.242 & 152.54 \\
\hline Catechin 2,6 & $\mathrm{C}_{15} \mathrm{H}_{14} \mathrm{O}_{6}+\mathrm{H}$ & 291.084 & 291.086 & -7.158 & (I) 165.17 \\
\hline Quercetin ${ }^{6}$ & $\mathrm{C}_{15} \mathrm{H}_{10} \mathrm{O}_{7}+\mathrm{H}$ & 303.052 & 303.05 & 5.231 & 175.45 \\
\hline 14-EET 6 & $\mathrm{C}_{20} \mathrm{H}_{32} \mathrm{O}_{3}+\mathrm{H}$ & 321.247 & 321.247 & 1.037 & 181.24 \\
\hline Erosone ${ }^{6}$ & $\mathrm{C}_{20} \mathrm{H}_{16} \mathrm{O}_{6}+\mathrm{H}$ & 353.102 & 353.102 & 0.377 & 154.89 \\
\hline Unknown & $\mathrm{n} / \mathrm{a}$ & 362.097 & $\mathrm{n} / \mathrm{a}$ & $\mathrm{n} / \mathrm{a}$ & 199.11 \\
\hline Disaccharide 2,5 & $\mathrm{C}_{12} \mathrm{H}_{22} \mathrm{O}_{11}+\mathrm{Na}$ & 365.105 & 365.105 & 1.096 & (I, II) 178.48 \\
\hline Disaccharide $^{1,2,5}$ & $\mathrm{C}_{12} \mathrm{H}_{22} \mathrm{O}_{6}+\mathrm{K}$ & 381.080 & 381.079 & 2.100 & (II) 180.54 \\
\hline Thy-diphosphate ${ }^{5}$ & $\mathrm{C}_{12} \mathrm{H}_{19} \mathrm{~N}_{4} \mathrm{O}_{7} \mathrm{P}_{2} \mathrm{~S}$ & 425.045 & 425.046 & -1.178 & (II) 182.21 \\
\hline Cya-ramnoside ${ }^{5}$ & $\mathrm{C}_{21} \mathrm{H}_{24} \mathrm{O}_{9}+\mathrm{H}$ & 434.120 & 434.121 & -1.844 & 161.61 \\
\hline Davidioside $^{6}$ & $\mathrm{C}_{21} \mathrm{H}_{24} \mathrm{O}_{9}+\mathrm{Na}$ & 443.132 & 443.131 & 1.130 & 169.62 \\
\hline Major (unknown) & $\mathrm{n} / \mathrm{a}$ & 524.148 & $\mathrm{n} / \mathrm{a}$ & $\mathrm{n} / \mathrm{a}$ & 201.79 \\
\hline Trisaccharide $1,2,5,6$ & $\mathrm{C}_{18} \mathrm{H}_{32} \mathrm{O}_{16}+\mathrm{Na}$ & 527.157 & 527.157 & 0.731 & (I) 215.94 \\
\hline Trisaccharide $1,5,6$ & $\mathrm{C}_{18} \mathrm{H}_{32} \mathrm{O}_{16}+\mathrm{K}$ & 543.131 & 543.132 & -1.415 & (II) 217.26 \\
\hline Major (unknown) & $\mathrm{n} / \mathrm{a}$ & 558.115 & $\mathrm{n} / \mathrm{a}$ & $\mathrm{n} / \mathrm{a}$ & 213.87 \\
\hline Gustroside $^{6}$ & $\mathrm{C}_{27} \mathrm{H}_{34} \mathrm{O}_{14}+\mathrm{Na}$ & 605.183 & 605.184 & -2.067 & 194.57 \\
\hline AsnGluGln ${ }^{6}$ & $\mathrm{C}_{25} \mathrm{H}_{33} \mathrm{~N}_{7} \mathrm{O}_{9}+\mathrm{K}$ & 614.192 & 614.197 & -7.463 & 196.50 \\
\hline Oligosacharide ${ }^{6}$ & $\mathrm{C}_{24} \mathrm{H}_{42} \mathrm{O}_{21}+\mathrm{Na}$ & 689.210 & 689.211 & -0.792 & 231.66 \\
\hline Major (unknown) & $\mathrm{n} / \mathrm{a}$ & 695.229 & $\mathrm{n} / \mathrm{a}$ & $\mathrm{n} / \mathrm{a}$ & 201.81 \\
\hline Oligosacharide ${ }^{1,6}$ & $\mathrm{C}_{24} \mathrm{H}_{42} \mathrm{O}_{21}+\mathrm{K}$ & 705.182 & 705.185 & -4.930 & 236.69 \\
\hline Major (unknown) & $\mathrm{n} / \mathrm{a}$ & 720.192 & $\mathrm{n} / \mathrm{a}$ & $\mathrm{n} / \mathrm{a}$ & 240.71 \\
\hline
\end{tabular}

Peak ID in database $\left({ }^{1}=\operatorname{ref}[21],{ }^{2}=[35],{ }^{3}=[51],{ }^{4}=[52],{ }^{5}=[47]\right),{ }^{6}=[$ Metlin]. DTCCS in database $((\mathrm{I})=[35],(\mathrm{II})=[47])$.

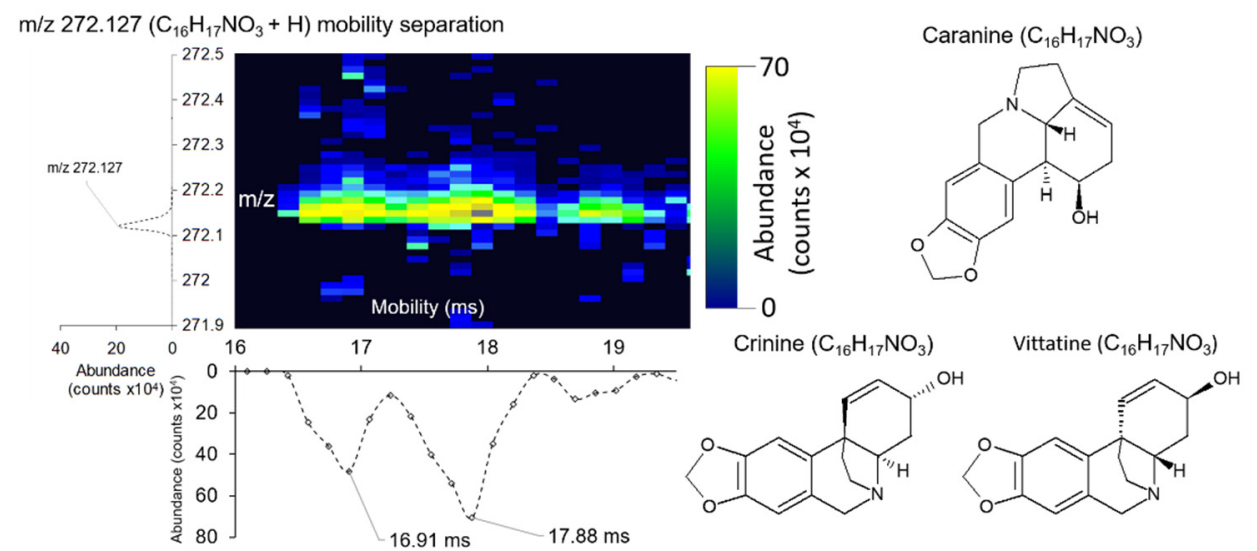

Figure 4. Example of how DTIMS is able to separate structural isomers in a single $A$. Cepa cell. Mobility separation of peak at $m / z 272.127\left(\mathrm{C}_{18} \mathrm{H}_{17} \mathrm{NO}_{3}+\mathrm{H}\right)$ into two species tentatively assigned as caranine $\left({ }^{\mathrm{DT}} \mathrm{CCS}=144.22 \AA^{2}\right)$ and crinine/vittatine $\left({ }^{\mathrm{DT}} \mathrm{CCS}=153.61 \AA^{2}\right)$.

\subsection{Comparison of In Situ Single Cell and Bulk Analysis}

To further demonstrate the benefit of in situ sampling, an A. Cepa extract (bulk analysis) was analyzed and compared against our in situ (single cell) analysis approach (Figure 5). Extraction was performed using the MPLEx protocol to extract metabolites from homogenized A. Cepa epidermal tissue as this protocol has previously been shown to be effective for the extraction of a broad range of molecular classes from plant tissues [53]. Analysis 
of the aqueous phase portion of the extract using our LAESI-MS microscope is shown in Figure 5. A small number of species were able to be assigned in the bulk extract (Figure 5a), which were mainly the saccharides listed in Table $1(\mathrm{~m} / \mathrm{z} 365.105, \mathrm{~m} / \mathrm{z} 381.080, \mathrm{~m} / \mathrm{z}$ 527.157, $m / z 543.131, m / z 689.210$, and $m / z$ 705.182) whereas a greater number of lower molecular weight species were detected using an in situ single cell approach (Figure 5b). A comparison of the number of spectral features (Figure 5c), and the number of an annotated species between the bulk and single cell spectra (Figure 5d) illustrates that single cell analysis produces greater molecular coverage than bulk analysis; with saccharides being the main molecular class detected in both sampling methods. This difference in metabolite profiles can be attributed to a combination of several factors, which include dilution of specific metabolites by non-metabolite containing cells in the bulk extract [54], insolubility of metabolites detected in situ in the aqueous phase of the MPLEx extract [55], cellular heterogeneity and metabolite heterogeneity across the cell population, as well as charge competition in ESI [56].

(a) Extract

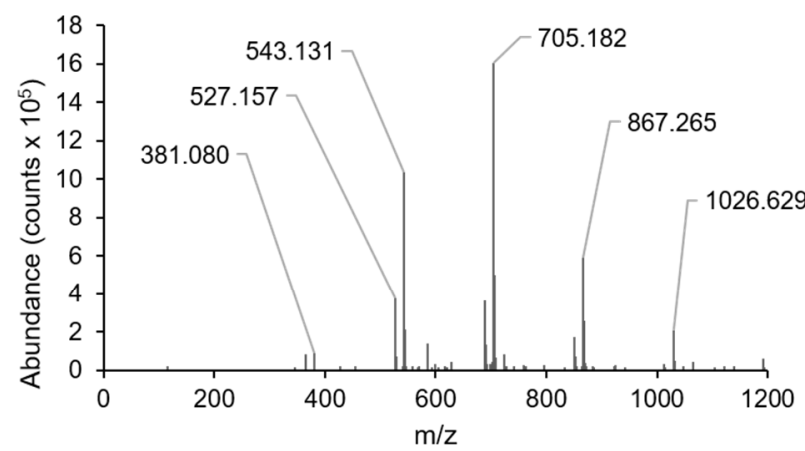

\section{(c) Comparison of spectral features}

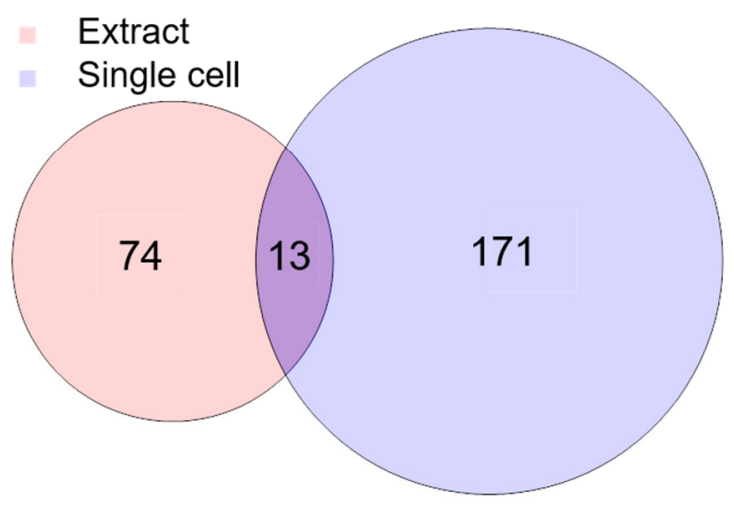

(b) Single cell

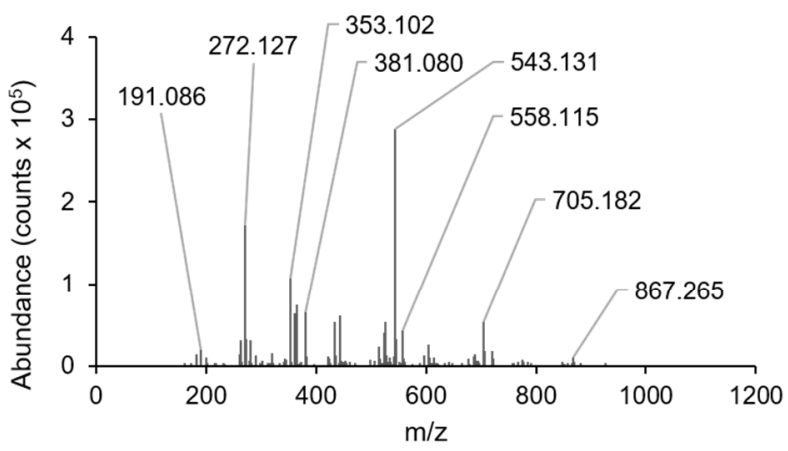

(d) Number of annotated species

\section{Extract \\ Single cell}

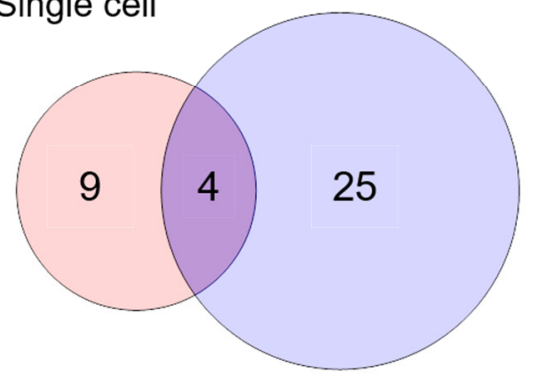

Figure 5. Spectral comparison of an aqueous extract from homogenized $A$. Cepa, and a single $A$. Cepa epidermal cell with LAESI-MS. (a) Positive ion spectrum acquired by ablation of a $3 \mu \mathrm{l}$ droplet of an $A$. Cepa tissue extract on a parafilm coated microscope slide with LAESI-MS, and (b) positive ion spectrum of an A. Cepa single epidermal cell. (c) Venn diagram showing the number of unique and shared spectral features between the aqueous extract and the single cell spectra. (d) Venn diagram showing the number of unique and shared annotated species between the aqueous extract and the single cell spectra.

\subsection{Variance in Sugar Abundance within Cell Population}

To demonstrate the ability of the LAESI microscope to analyze individual $A$. Cepa epidermal cells in high throughput, individual cells were optically selected, and their cell centroid coordinates were entered into the LAESI microscope. This approach was able to automatically drive the stage so that the focused laser beam was directly over each cell center and acquire a mass spectrum in situ. From our analysis, we observed that all saccharide species in Table 1 were present in this 60 -cell dataset. To determine any variance in saccharide abundance (i.e., metabolic noise), background subtracted peak intensities of the 
mono-, di-, tri-, and tetra-saccharides were plotted against cell frequency (Figure 6). From this, variations in saccharide abundance were observed. Specifically, two different populations of cells were present based on the amount of monosaccharide $(\mathrm{m} / \mathrm{z} 219.026)$ detected (Figure 6a). A bimodal distribution was observed for the monosaccharide (Figure 6a) with both gamma and gaussian distributions, whereas unimodal (gaussian) distributions were present for the other saccharides (Figure $6 \mathrm{~b}-\mathrm{d}$ ). These results indicate that subpopulations of $A$. Cepa cells in the epidermis can be discriminated based on monosaccharide abundance (Figure 6a). The metabolic noise $\left(\eta_{\text {met }}{ }^{2}\right)$ based on saccharide abundance, ordered by the

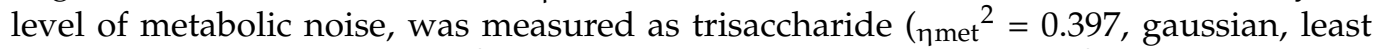

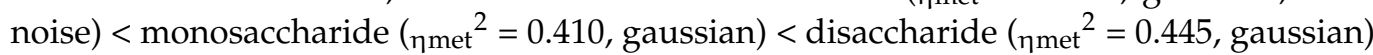
$<$ tetrasaccharide $\left(\right.$ nmet $^{2}=0.550$, gaussian $)<$ monosaccharide $\left(\eta_{\text {met }}^{2}=0.566\right.$, gamma, most noise). These results indicate that the metabolic noise level $\left(\mathrm{\eta met}^{2}\right)$ is greater than the technical noise level $\left(_{\eta t_{\text {tech }}}{ }^{2}=0.380\right)$ measured for the saccharide standard, maltose (Figure S2c) indicating that these results are significant.

(a)

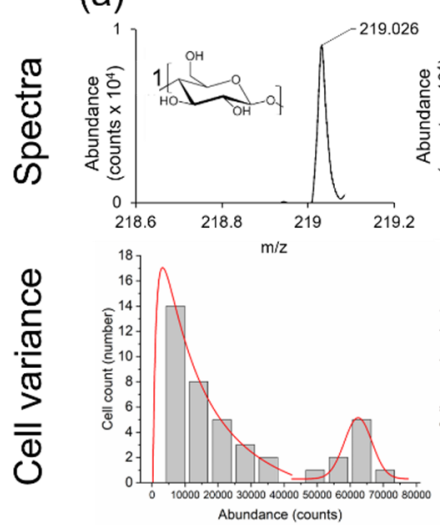

(b)
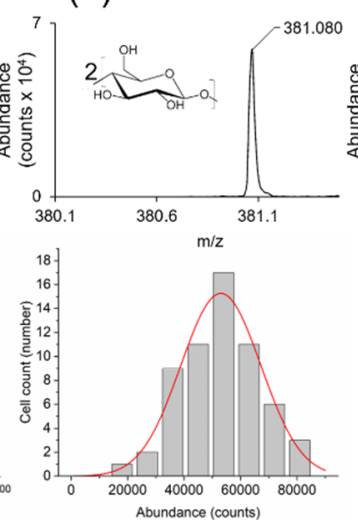

(c)
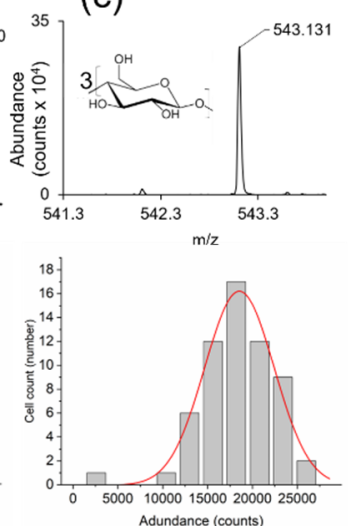

(d)
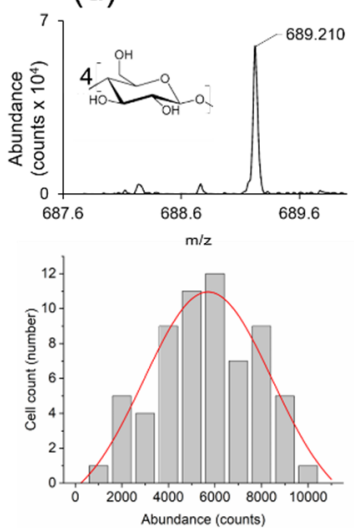

Figure 6. Exploring the variance in the abundance of saccharides within single cells of $A$. Cepa. $\mathrm{i}=60$ single cells. Monosaccharide (a), disaccharide (b), trisaccharide (c), tetrasaccharide (d). Spectra and structures for each of the saccharides (top row), and abundance (counts) for the saccharides within the 60 cells set (bottom row). Distribution fits are also shown (red lines).

\section{Materials and Methods}

\subsection{Materials}

Methanol, water, formic acid, verapamil, and maltose were purchased (Fisher Scientific, Hampton, NH, USA) at HPLC-grade or higher purity. Agilent Low Concentration Tuning Mix (Agilent Technologies, Santa Clara, CA, USA) was used for mass and mobility calibrations. Verapamil concentration standards for assessment of instrument sensitivity and limit of detection were generated from serial dilutions of a stock solution $\left(1.0 \times 10^{-3} \mathrm{~mol} / \mathrm{L}\right)$. Red onion (Allium Cepa) was purchased from a local supermarket.

\subsection{Instrument Design}

The design of the LAESI-DTIMS instrument is illustrated in Figure 1. The XYZ stage (Zaber, Vancouver, BC, Canada) has a Peltier Plate module (Thermo Fisher Scientific, Waltham, MA, USA) that regulates the stage temperature and holds the glass mounted samples [25]. A white light source was directed through a dichroic mirror (long pass, cut-on wavelength, $605 \mathrm{~nm}$, Thorlabs Inc, Newton, NJ, USA) and then through a reflective objective ( $\times 15$, Thorlabs Inc, Newton, NJ, USA), and a CCD (Thorlabs Inc., Newton, NJ, USA) mounted at the top of the optical stack recorded images of the sample surface. The microscope control software ( $\mu$ Manager [58]) allowed for the specification of the number of image tiles (stage positions) to record. $\mu$ Manager moved the stage to each tile position, performed autofocusing by moving the stage $\mathrm{Z}$ axis by specifying large $(10 \mu \mathrm{m} \times 20$ steps $)$ and fine adjustment $(0.1 \mu \mathrm{m} \times 20$ steps $)$ over a range of $Z$ heights. By 
recording images at each $\mathrm{Z}$ location, it selected the image with the best focus based upon its sharpness metrics [58]. The stage then moved to the next position and repeated the process. Images were compiled and image arrays were extracted into a separate processing program (Fiji) [59]. The rolling ball BASIC plugin [60] removed vignetting in individual tiles, then stitching was performed by specifying a maximum percentage overlap $(18 \%$ overlap) to shift images laterally and horizontally. Image tiles were combined into an array with $X / Y$ number of pixels. Pixel coordinates were converted to stage coordinates by inputting pixel positions in the stitched image array into a home-built calculator (developed in LabView) [61] and by specifying size dimensions $(\mu \mathrm{m})$ of individual image tiles. Stage positions for individual cell centers in the large area stitch were then manually selected, and a list of cell center positions was exported as a .csv file format. The cell center list was uploaded into our home-built LabView-based LAESI software [61], which moved the stage to each position sequentially for LAESI-DTIMS analysis. The mid IR laser source $(\lambda=2940 \mathrm{~nm}$; OPOTEK, Carlsbad, CA, USA), was directed through a reflective objective, through an optical train that contained the dichroic mirror (long pass, cut-on wavelength, $605 \mathrm{~nm}$, Thorlabs Inc, Newton, NJ, USA) that the white light source passed through, and this permitted in-line optical microscopy. The DTIMS contained a $79 \mathrm{~cm}$ length linear drift cell and coupled to a quadrupole time-of-flight (QTOF) mass spectrometer (6538 QTOF, Agilent Technologies, Santa Clara, CA, USA). This systems has been described previously in detail [62]. For all experiments the following parameters were used for the DTIMS: inlet capillary $(370 \mathrm{~V})$, high pressure funnel entrance $(360 \mathrm{~V})$, high pressure funnel exit $(170 \mathrm{~V})$, ion funnel trap entrance $(200 \mathrm{~V})$, ion funnel trap exit $(30 \mathrm{~V})$, ion funnel trap conductance limiting orifice voltage $(10 \mathrm{~V})$, drift tube entrance $(1900 \mathrm{~V})$, drift tube exit $(354 \mathrm{~V})$, rear ion funnel entrance $(340 \mathrm{~V})$, rear ion funnel exit $(160 \mathrm{~V})$, short quadrupole bias $(116 \mathrm{~V})$, conductance limiting orifice $(114 \mathrm{~V})$, segmented quadrupole entrance $(110 \mathrm{~V})$, segmented quadrupole exit $(30 \mathrm{~V})$, and conductance limiting orifice $(10 \mathrm{~V})$. Nitrogen was used as a buffer gas in the drift tube. The pressure in high pressure funnel (3.77 Torr), Ion funnel trap (4.56 Torr), and short quadrupole ( $454 \mathrm{mTorr}$ ). The drift cell temperature was $26^{\circ} \mathrm{C}$. Multiplexing was used. MS-dependent laser triggering is described in detail elsewhere [25].

\subsection{Sensitivity Measurements}

Verapamil hydrochloride standard solutions were prepared in nano-pure deionized water $(18.2 \Omega)$. The series of concentration standards used to assess sensitivity were prepared by serial dilution of a $\left(1.0 \times 10^{-3} \mathrm{~mol} / 1\right.$ stock solution) to generate solution concentrations of $1.0 \times 10^{-3}, 1.0 \times 10^{-4}, 1.0 \times 10^{-5}, 1.0 \times 10^{-6}$, and $1.0 \times 10^{-7} \mathrm{~mol} / \mathrm{L}$. $3 \mu \mathrm{L}$ droplets from each solution were pipetted onto a parafilm covered microscope slide. The droplets were ablated using the mid IR laser source either in sync with the ion trap of the MS opening (MS-triggered mode) or by freely firing the laser (non-triggered mode). On average, 60 laser shots were required to ablate the entire droplet. 10 technical replicates were taken for each concentration. For MS-triggered mode, the laser is externally triggered via the custom built LabView Software, and a Q-switch delay of $665 \mu$ s, pulse rate of $20 \mathrm{kHz}$, and an accumulation time $50 \mathrm{~ms}$ were used. For non-triggered mode, the laser was internally triggered, and a pulse rate of $20 \mathrm{kHz}$ and a Q-switch delay of $165 \mu \mathrm{s}$ was used. Note, there is a $\sim 500 \mu$ delay in externally triggering the flash lamp, which is why there is a difference in the Q-switch delay between MS-triggered and non-triggered modes. The laser power exiting the laser was measured as $6.166 \mathrm{~mJ}(\mathrm{RSD}=4.59 \%)$ using a C-series laser power meter (Thorlabs Inc, Newton, NJ) using this Q-switch delay. However, since the laser is attenuated as it passes through the dichroic mirror, the laser power was approximated to be $1.065 \mathrm{~mJ}$ prior to passing through the dual objective lens. This laser power was maintained for all experiments.

\subsection{Optimizing LAESI-DTIMS Analysis}

A. Cepa epidermal tissue mounted on a glass microscope slide was placed on the Peltier stage at $16^{\circ} \mathrm{C}$. The sample stage was leveled prior to this using a bubble level ruler 
(Johnson Level \& Tool Mfg. Co., Inc., Mequon, WI, USA). An electrospray (+1635 V) of (1:1 MeOH/water with $0.1 \%$ formic acid was applied orthogonal to the stage surface at a constant flow rate $(0.8 \mu \mathrm{L} / \mathrm{min})$, and the instrument-inlet capillary voltage was held at $+370.29 \mathrm{~V}$. The electrospray tip was placed $9 \mathrm{~mm}$ from the MS inlet. The sample was then moved in $Z$ direction to $6.5 \mathrm{~mm}$ below the MS inlet capillary and the microscope objective was moved in $Z$ to bring the $A$. Cepa cells into focus. Ion transmission efficiency was maximized by freely firing the laser in non-triggered mode at $10 \mathrm{kHz}$ (Q-switch delay of $165 \mu \mathrm{s}$ ), while moving the stage in the $\mathrm{Z}$ axis by $0.1 \mathrm{~mm}$ increments to maximize the total ion count $\left(\mathrm{TIC}_{\max }\right)$. The sample height was recorded at the $\mathrm{TIC}_{\max }$, then the objective was repositioned in $\mathrm{Z}$ to bring the image into focus. The sample stage was moved to adjacent locations, and the TIC was measured in triggered mode $(20 \mathrm{kHz}, 50 \mathrm{~ms}$ accumulation time, 2 laser pulses) moving the stage in $\mathrm{Z}$ by $0.1 \mathrm{~mm}$ increments between adjacent positions to optimize ion transmission which was recorded as a sample height of $6.13 \mathrm{~mm}$ from the MS inlet capillary to the sample surface.

ZAP-IT laser alignment paper (Concord, NH, USA) was then placed on the sample stage, and one laser shot was fired over the range of sample $Z$ heights $(6.01-6.18 \mathrm{~mm}$, distance from MS inlet to sample surface) at adjacent areas on the ZAP-IT paper. Images of these areas were recorded with the CCD, and the ratio of width to length for the impact craters was compared (i.e., ratio $=1$ is ideal for a $\mathrm{TEM}_{00}$ beam), which was determined to be a stage $Z$ height of $6.06 \mathrm{~mm}$ (distance from MS inlet to sample surface). This information is shown in Figure S4. Onion cells on microscope slides were then placed back on the stage, and the laser was fired at a $Z$ stage height of $6.06 \mathrm{~mm}$ (best laser focus) and the total ion count observed, and impact crater was measured to ensure ablation of singular cells.

\subsection{A. Cepa Cell Analysis}

Spectra with mobility analysis were collected from 60 individual red onion (Allium Cepa) epidermal cells in positive ion mode. Briefly, $3 \mathrm{~cm}^{2}$ squares from the 2 nd layer of an $A$. Cepa bulb were placed on a microscope slide, then the slide was placed on the Peltier-cooled stage $\left(16^{\circ} \mathrm{C}\right)$. An image of the $A$. Cepa tissue was recorded with the optical microscope component, then individual cell centers were manually selected, and exported into the cell center list for LAESI-MS analysis. Electrospray (+1635 V) of 1:1 MeOH/water with $0.1 \%$ formic acid was applied orthogonal to the stage surface at a constant flow rate $(0.8 \mu \mathrm{L} / \mathrm{min})$, and the instrument-inlet capillary voltage was held at $+370 \mathrm{~V}$. The number of laser pulses $(n=2)$, number of sample positions, the laser Q-switch delay, and pulse frequency $(20 \mathrm{kHz})$ were all set in the custom LabView software [25]. Q-switch delay of $665 \mu \mathrm{s}$, pulse rate of $20 \mathrm{kHz}$, and an accumulation time $50 \mathrm{~ms}$ was used for all single cell experiments. The stage height ( $\mathrm{z}$ ) was maintained at $6.13 \mathrm{~mm}$ (distance from the MS inlet capillary to the sample surface) throughout the separate measurements. Three independent tissue sections, 30 individual cells in each of the section were measured representing a sample set of $n=90$. This sample set was filtered down to 60 cells following LAESI-DTIMS analysis by inspecting the impact craters using our optical train. Filtering was based on the precision of the ablation spot to the cell center, as a number of the cells analyzed presented with impact craters near the cellular grain boundary which would introduce potential error into the single cell dataset.

\subsection{MPLEx Preparation and Analysis}

MPLEx extraction was performed as described in the literature [53]. Briefly, homogenized $A$. Cepa tissue (100 mg) was resuspended in water, and 5 volumes $(0.2 \mathrm{~mL})$ of cold $\left(20^{\circ} \mathrm{C}\right)$ chloroform-methanol $(2: 1 / v: v)$ solution was added. Samples were incubated for $5 \mathrm{~min}$ on ice, vortex mixed for $1 \mathrm{~min}$, and centrifuged at $12,000 \mathrm{rpm}$ for $10 \mathrm{~min}$ at $4{ }^{\circ} \mathrm{C}$. The upper aqueous phase containing the hydrophilic metabolites were collected in glass autosampler vials. Analysis was performed by dispensing $3 \mu \mathrm{L}$ droplets of the metabolite extract onto parafilm coated microscope slides. On average 60 laser shots were required to ablate the entire droplet, and 10 technical replicates were analyzed of these samples. 


\subsection{Data Analysis \& Software}

All spectra were processed using the Pacific Northwest National Laboratory (PNNL) unified ion mobility format (UIMF) viewer [63]. Calibration of mobility to ${ }^{\mathrm{DT}}$ CCS was performed with Agilent tune mix $(\mathrm{m} / \mathrm{z}$ 118.086, $\mathrm{m} / \mathrm{z}$ 332.048, $\mathrm{m} / \mathrm{z}$ 622.029, $\mathrm{m} / \mathrm{z}$ 922.010, $m / z 1221.991, m / z 1521.971$ ). Calibrated spectra were exported into mMass (open source software) for data processing [64]. Technical and metabolic noise with distribution fitting was performed in OriginPro (version 2021, OriginLab Corporation, Northampton, MA, USA).

\section{Conclusions}

Here, the development of a LAESI-IMS system integrated with an optical microscope for ambient sampling of in situ single cells is presented. This source configuration is effective for analyzing A. Cepa cells in a high throughput approach. Specifically, the addition of the cell recognition software, wherein spatial coordinates are assigned to individual cells, can be utilized for rapid single cell analysis. Moreover, dual channel imaging can be achieved with the system by integrating additional optics and cameras (i.e., charge coupled devices) to permit multiwavelength microscopy (e.g., brightfield plus fluorescence). Additionally, the software integrated into this LAESI microscope is all open source, therefore each individual software package can be more readily combined into a dual LAESI/microscope due to the availability of the source code. The final benefit of our LAESI microscope is that the source component can be adapted to various mass spectrometers, meaning that higher mobility resolution methods can be explored for improved separation of isotopologues within single cells [57]. The cells we analyzed here were relatively large in comparison to smaller cell sizes (e.g., mammalian). As such, in further studies we will explore higher resolution optics for improving spatial resolutions, as well as look to enhance the sensitivity of our system by investigating methods to increase ion transmission efficiency, all in effort to make single cell analysis of smaller cells possible.

Supplementary Materials: The following are available online at https:/ /www.mdpi.com/article/10 $.3390 /$ metabo11040200/s1, Figure S1: Determining the sensitivity of the LAESI-DTIMS microscope with verapamil, Figure S2: Technical noise from ablation of droplets of standards, Figure S3: Images of laser spots on ZAP-IT paper in beam focusing experiments over a range of $\mathrm{Z}$ stage heights, Figure S4: The effect of sample stage height on spot uniformity and spot size, Figure S5: Large area stitched image mosaic of an A. Cepa tissue section, Table S1: Raw counts of different saccharide species detected in 60 A. Cepa cells.

Author Contributions: M.J.T. conceptualization, investigation, methodology, formal analysis, data curation, writing - original draft preparation; C.R.A. conceptualization, investigation, methodology, funding acquisition, writing-review and editing; A.L. software, writing-review and editing; Y.M.I. formal analysis, writing-review and editing; S.M., S.A.S., and A.V., instrument conceptualization, writing-review and editing. All authors have read and agreed to the published version of the manuscript.

Funding: The research was supported by the Intramural program at EMSL (grid.436923.9), a DOE Office of Science User Facility sponsored by the Biological and Environmental Research program and operated under Contract No. DE-AC05-76RL01830.

Institutional Review Board Statement: Not applicable.

Informed Consent Statement: Not applicable.

Data Availability Statement: The data presented in this study are available in the Supplementary Material.

Conflicts of Interest: The authors declare no conflict of interest. 


\section{References}

1. Macaulay, I.C.; Ponting, C.P.; Voet, T. Single-Cell Multiomics: Multiple Measurements from Single Cells. Trends Genet. 2017, 33, 155-168. [CrossRef]

2. Taylor, M.J.; Lukowski, J.K.; Anderton, C.R. Spatially Resolved Mass Spectrometry at the Single Cell: Recent Innovations in Proteomics and Metabolomics. J. Am. Soc. Mass Spectrom. 2021. [CrossRef]

3. Choi, H.; Yang, Z.; Weisshaar, J.C. Single-cell, real-time detection of oxidative stress induced inEscherichia coliby the antimicrobial peptide CM15. Proc. Natl. Acad. Sci. USA 2015, 112, E303-E310. [CrossRef] [PubMed]

4. Brock, A.; Chang, H.; Huang, S. Non-genetic heterogeneity-A mutation-independent driving force for the somatic evolution of tumours. Nat. Rev. Genet. 2009, 10, 336-342. [CrossRef] [PubMed]

5. Raj, A.; Van Oudenaarden, A. Nature, Nurture, or Chance: Stochastic Gene Expression and Its Consequences. Cell 2008, 135, 216-226. [CrossRef]

6. Wilson, N.K.; Kent, D.G.; Buettner, F.; Shehata, M.; Macaulay, I.C.; Calero-Nieto, F.J.; Castillo, M.S.; Oedekoven, C.A.; Diamanti, E.; Schulte, R.; et al. Combined Single-Cell Functional and Gene Expression Analysis Resolves Heterogeneity within Stem Cell Populations. Cell Stem Cell 2015, 16, 712-724. [CrossRef] [PubMed]

7. Bendall, S.C.; Simonds, E.F.; Qiu, P.; Amir, E.-A.D.; Krutzik, P.O.; Finck, R.; Bruggner, R.V.; Melamed, R.; Trejo, A.; Ornatsky, O.I.; et al. Single-Cell Mass Cytometry of Differential Immune and Drug Responses Across a Human Hematopoietic Continuum. Science 2011, 332, 687-696. [CrossRef] [PubMed]

8. Neumann, E.K.; Ellis, J.F.; Triplett, A.E.; Rubakhin, S.S.; Sweedler, J.V. Lipid Analysis of 30000 Individual Rodent Cerebellar Cells Using High-Resolution Mass Spectrometry. Anal. Chem. 2019, 91, 7871-7878. [CrossRef]

9. Neumann, E.K.; Comi, T.J.; Rubakhin, S.S.; Sweedler, J.V. Lipid Heterogeneity between Astrocytes and Neurons Revealed by Single-Cell MALDI-MS Combined with Immunocytochemical Classification. Angew. Chem. 2019, 131, 5971-5975. [CrossRef]

10. Amantonico, A.; Urban, P.L.; Fagerer, S.R.; Balabin, R.M.; Zenobi, R. Single-Cell MALDI-MS as an Analytical Tool for Studying Intrapopulation Metabolic Heterogeneity of Unicellular Organisms. Anal. Chem. 2010, 82, 7394-7400. [CrossRef]

11. Dong, Y.; Li, B.; Malitsky, S.; Rogachev, I.; Aharoni, A.; Kaftan, F.; Svatoš, A.; Franceschi, P. Sample Preparation for Mass Spectrometry Imaging of Plant Tissues: A Review. Front. Plant Sci. 2016, 7, 60. [CrossRef] [PubMed]

12. Yoon, S.; Lee, T.G. Biological tissue sample preparation for time-of-flight secondary ion mass spectrometry (ToF-SIMS) imaging. Nano Converg. 2018, 5, 1-13. [CrossRef]

13. Van Nuffel, S.; Elie, N.; Yang, E.; Nouet, J.; Touboul, D.; Chaurand, P.; Brunelle, A. Insights into the MALDI Process after Matrix Deposition by Sublimation Using 3D ToF-SIMS Imaging. Anal. Chem. 2018, 90, 1907-1914. [CrossRef] [PubMed]

14. Li, B.; Zhang, Y.; Ge, J.; Liu, K.; Li, P. Sample preparation for mass spectrometry imaging of leaf tissues: A case study on analyte delocalization. Anal. Bioanal. Chem. 2018, 410, 7449-7456. [CrossRef]

15. Anderson, D.M.G.; Floyd, K.A.; Barnes, S.; Clark, J.M.; Clark, J.I.; Mchaourab, H.; Schey, K.L. A method to prevent protein delocalization in imaging mass spectrometry of non-adherent tissues: Application to small vertebrate lens imaging. Anal. Bioanal. Chem. 2015, 407, 2311-2320. [CrossRef] [PubMed]

16. Bokhart, M.T.; Manni, J.; Garrard, K.P.; Ekelöf, M.; Nazari, M.; Muddiman, D.C. IR-MALDESI Mass Spectrometry Imaging at 50 Micron Spatial Resolution. J. Am. Soc. Mass Spectrom. 2017, 28, 2099-2107. [CrossRef] [PubMed]

17. Shrestha, B.; Sripadi, P.; Reschke, B.R.; Henderson, H.D.; Powell, M.J.; Moody, S.A.; Vertes, A. Subcellular Metabolite and Lipid Analysis of Xenopus laevis Eggs by LAESI Mass Spectrometry. PLoS ONE 2014, 9, e115173. [CrossRef] [PubMed]

18. Stopka, S.A.; Agtuca, B.J.; Koppenaal, D.W.; Paša-Tolić, L.; Stacey, G.; Vertes, A.; Anderton, C.R. Laser-ablation electrospray ionization mass spectrometry with ion mobility separation reveals metabolites in the symbiotic interactions of soybean roots and rhizobia. Plant J. 2017, 91, 340-354. [CrossRef] [PubMed]

19. Agtuca, B.J.; Stopka, S.A.; Evans, S.; Samarah, L.; Liu, Y.; Xu, D.; Stacey, M.G.; Koppenaal, D.W.; Paša-Tolić, L.; Anderton, C.R.; et al. Metabolomic profiling of wild-type and mutant soybean root nodules using laser-ablation electrospray ionization mass spectrometry reveals altered metabolism. Plant J. 2020, 103, 1937-1958. [CrossRef] [PubMed]

20. Samarah, L.Z.; Khattar, R.; Tran, T.H.; Stopka, S.A.; Brantner, C.A.; Parlanti, P.; Veličković, D.; Shaw, J.B.; Agtuca, B.J.; Stacey, G.; et al. Single-Cell Metabolic Profiling: Metabolite Formulas from Isotopic Fine Structures in Heterogeneous Plant Cell Populations. Anal. Chem. 2020, 92, 7289-7298. [CrossRef]

21. Shrestha, B.; Vertes, A. In Situ Metabolic Profiling of Single Cells by Laser Ablation Electrospray Ionization Mass Spectrometry. Anal. Chem. 2009, 81, 8265-8271. [CrossRef] [PubMed]

22. Stolee, J.A.; Shrestha, B.; Mengistu, G.; Vertes, A. Observation of Subcellular Metabolite Gradients in Single Cells by Laser Ablation Electrospray Ionization Mass Spectrometry. Angew. Chem. Int. Ed. 2012, 51, 10386-10389. [CrossRef]

23. Stopka, S.A.; Khattar, R.; Agtuca, B.J.; Anderton, C.R.; Paša-Tolić, L.; Stacey, G.; Vertes, A. Metabolic Noise and Distinct Subpopulations Observed by Single Cell LAESI Mass Spectrometry of Plant Cells in situ. Front. Plant Sci. 2018, 9, 9. [CrossRef]

24. Kulkarni, P.; Wilschut, R.A.; Verhoeven, K.J.F.; Van Der Putten, W.H.; Garbeva, P. LAESI mass spectrometry imaging as a tool to differentiate the root metabolome of native and range-expanding plant species. Planta 2018, 248, 1515-1523. [CrossRef] [PubMed]

25. Stopka, S.A.; Samarah, L.Z.; Shaw, J.B.; Liyu, A.V.; Veličković, D.; Agtuca, B.J.; Kukolj, C.; Koppenaal, D.W.; Stacey, G.; Paša-Tolić, L.; et al. Ambient Metabolic Profiling and Imaging of Biological Samples with Ultrahigh Molecular Resolution Using Laser Ablation Electrospray Ionization 21 Tesla FTICR Mass Spectrometry. Anal. Chem. 2019, 91, 5028-5035. [CrossRef] 
26. Qi, Y.; Fu, P.; Volmer, D.A. Analysis of natural organic matter via fourier transform ion cyclotron resonance mass spectrometry: An overview of recent non-petroleum applications. Mass Spectrom. Rev. 2020, 21634. [CrossRef] [PubMed]

27. Ekelöf, M.; Dodds, J.; Khodjaniyazova, S.; Garrard, K.P.; Baker, E.S.; Muddiman, D.C. Coupling IR-MALDESI with Drift Tube Ion Mobility-Mass Spectrometry for High-Throughput Screening and Imaging Applications. J. Am. Soc. Mass Spectrom. 2020, 31, 642-650. [CrossRef] [PubMed]

28. Rivera, E.S.; Djambazova, K.V.; Neumann, E.K.; Caprioli, R.M.; Spraggins, J.M. Integrating Ion Mobility and Imaging Mass Spectrometry for Comprehensive Analysis of Biological Tissues: A brief review and perspective. J. Mass Spectrom. 2020, 55, e4614. [CrossRef]

29. Shrestha, B.; Vertes, A. High-Throughput Cell and Tissue Analysis with Enhanced Molecular Coverage by Laser Ablation Electrospray Ionization Mass Spectrometry Using Ion Mobility Separation. Anal. Chem. 2014, 86, 4308-4315. [CrossRef]

30. Stopka, S.A.; Shrestha, B.; Maréchal, É.; Falconet, D.; Vertes, A. Metabolic transformation of microalgae due to light acclimation and genetic modifications followed by laser ablation electrospray ionization mass spectrometry with ion mobility separation. Analyst 2014, 139, 5945-5953. [CrossRef] [PubMed]

31. Li, H.; Smith, B.K.; Márk, L.; Nemes, P.; Nazarian, J.; Vertes, A. Ambient molecular imaging by laser ablation electrospray ionization mass spectrometry with ion mobility separation. Int. J. Mass Spectrom. 2015, 377, 681-689. [CrossRef]

32. Stopka, S.A.; Mansour, T.R.; Shrestha, B.; Maréchal, É.; Falconet, D.; Vertes, A. Turnover rates in microorganisms by laser ablation electrospray ionization mass spectrometry and pulse-chase analysis. Anal. Chim. Acta 2016, 902, 1-7. [CrossRef]

33. Comi, T.J.; Neumann, E.K.; Do, T.D.; Sweedler, J.V. microMS: A Python Platform for Image-Guided Mass Spectrometry Profiling. J. Am. Soc. Mass Spectrom. 2017, 28, 1919-1928. [CrossRef]

34. Siegel, T.P.; Hamm, G.; Bunch, J.; Cappell, J.; Fletcher, J.S.; Schwamborn, K. Mass Spectrometry Imaging and Integration with Other Imaging Modalities for Greater Molecular Understanding of Biological Tissues. Mol. Imaging Biol. 2018, 20, 888-901. [CrossRef]

35. Zheng, X.; Aly, N.A.; Zhou, Y.; Dupuis, K.T.; Bilbao, A.; Paurus, V.L.; Orton, D.J.; Wilson, R.; Payne, S.H.; Smith, R.D.; et al. A structural examination and collision cross section database for over 500 metabolites and xenobiotics using drift tube ion mobility spectrometry. Chem. Sci. 2017, 8, 7724-7736. [CrossRef] [PubMed]

36. Compton, L.R.; Reschke, B.; Friend, J.; Powell, M.; Vertes, A. Remote laser ablation electrospray ionization mass spectrometry for non-proximate analysis of biological tissues. Rapid Commun. Mass Spectrom. 2014, 29, 67-73. [CrossRef] [PubMed]

37. Hines, K.M.; Ross, D.H.; Davidson, K.L.; Bush, M.F.; Xu, L. Large-Scale Structural Characterization of Drug and Drug-Like Compounds by High-Throughput Ion Mobility-Mass Spectrometry. Anal. Chem. 2017, 89, 9023-9030. [CrossRef]

38. Rosen, E.P.; Bokhart, M.T.; Nazari, M.; Muddiman, D.C. Influence of C-Trap Ion Accumulation Time on the Detectability of Analytes in IR-MALDESI MSI. Anal. Chem. 2015, 87, 10483-10490. [CrossRef]

39. Nemes, P.; Vertes, A. Laser Ablation Electrospray Ionization for Atmospheric Pressure, in Vivo, and Imaging Mass Spectrometry. Anal. Chem. 2007, 79, 8098-8106. [CrossRef]

40. Tang, K.; Shvartsburg, A.A.; Lee, H.-N.; Prior, D.C.; Buschbach, M.A.; Li, F.; Tolmachev, A.V.; Anderson, G.A.; Smith, R.D. High-Sensitivity Ion Mobility Spectrometry/Mass Spectrometry Using Electrodynamic Ion Funnel Interfaces. Anal. Chem. 2005, 77, 3330-3339. [CrossRef] [PubMed]

41. Kiss, A.; Heeren, R.M.A. Size, weight and position: Ion mobility spectrometry and imaging MS combined. Anal. Bioanal. Chem. 2011, 399, 2623-2634. [CrossRef] [PubMed]

42. Ewing, M.A.; Glover, M.S.; Clemmer, D.E. Hybrid ion mobility and mass spectrometry as a separation tool. J. Chromatogr. A 2016, 1439, 3-25. [CrossRef]

43. Hoaglund, C.S.; Valentine, S.J.; Sporleder, C.R.; Reilly, J.P.; Clemmer, D.E. Three-Dimensional Ion Mobility/TOFMS Analysis of Electrosprayed Biomolecules. Anal. Chem. 1998, 70, 2236-2242. [CrossRef]

44. Doutre, C.; Nasiopoulos, P. Fast vignetting correction and color matching for panoramic image stitching. In Proceedings of the 2009 16th IEEE International Conference on Image Processing (ICIP), Cairo, Egypt, 7-10 November 2009; pp. 709-712.

45. Reddy, J.P.; Rhim, J.-W. Extraction and Characterization of Cellulose Microfibers from Agricultural Wastes of Onion and Garlic. J. Nat. Fibers 2018, 15, 465-473. [CrossRef]

46. Kaszycki, J.L.; La Rotta, A.; Colsch, B.; Fenaille, F.; Dauly, C.; Kamleh, A.; Wu, C. Separation of biologically relevant isomers on an Orbitrap mass spectrometer using high-resolution drift tube ion mobility and varied drift gas mixtures. Rapid Commun. Mass Spectrom. 2019, 33, 3-10. [CrossRef]

47. Picache, J.A.; Rose, B.S.; Balinski, A.; Leaptrot, K.L.; Sherrod, S.D.; May, J.C.; McLean, J.A. Collision cross section compendium to annotate and predict multi-omic compound identities. Chem. Sci. 2018, 10, 983-993. [CrossRef]

48. Pang, X.; Jia, C.; Chen, Z.; Li, L. Structural Characterization of Monomers and Oligomers of D-Amino Acid-Containing Peptides Using T-Wave Ion Mobility Mass Spectrometry. J. Am. Soc. Mass Spectrom. 2016, 28, 110-118. [CrossRef] [PubMed]

49. Jia, C.; Lietz, C.B.; Yu, Q.; Li, L. Site-Specific Characterization of d-Amino Acid Containing Peptide Epimers by Ion Mobility Spectrometry. Anal. Chem. 2014, 86, 2972-2981. [CrossRef] [PubMed]

50. Fouque, K.J.D.; Garabedian, A.; Porter, J.; Baird, M.; Pang, X.; Williams, T.D.; Li, L.; Shvartsburg, A.; Fernandez-Lima, F. Fast and Effective Ion Mobility-Mass Spectrometry Separation ofd-Amino-Acid-Containing Peptides. Anal. Chem. 2017, 89, 11787-11794. [CrossRef]

51. Zhou, Z.; Shen, X.; Tu, J.; Zhu, Z.-J. Large-Scale Prediction of Collision Cross-Section Values for Metabolites in Ion Mobility-Mass Spectrometry. Anal. Chem. 2016, 88, 11084-11091. [CrossRef] 
52. Böttcher, C.; Krähmer, A.; Stürtz, M.; Widder, S.; Schulz, H. Comprehensive metabolite profiling of onion bulbs (Allium cepa) using liquid chromatography coupled with electrospray ionization quadrupole time-of-flight mass spectrometry. Metabolomics 2017, 13, 35. [CrossRef]

53. Nakayasu, E.S.; Nicora, C.D.; Sims, A.C.; Burnum-Johnson, K.E.; Kim, Y.-M.; Kyle, J.E.; Matzke, M.M.; Shukla, A.K.; Chu, R.K.; Schepmoes, A.A.; et al. MPLEx: A Robust and Universal Protocol for Single-Sample Integrative Proteomic, Metabolomic, and Lipidomic Analyses. mSystems 2016, 1, e00043-16. [CrossRef]

54. Zhang, L.; Khattar, N.; Kemenes, I.; Kemenes, G.; Zrinyi, Z.; Pirger, Z.; Vertes, A. Subcellular Peptide Localization in Single Identified Neurons by Capillary Microsampling Mass Spectrometry. Sci. Rep. 2018, 8, 12227. [CrossRef] [PubMed]

55. Evers, T.M.J.; Hochane, M.; Tans, S.J.; Heeren, R.M.A.; Semrau, S.; Nemes, P.; Mashaghi, A. Deciphering Metabolic Heterogeneity by Single-Cell Analysis. Anal. Chem. 2019, 91, 13314-13323. [CrossRef] [PubMed]

56. Tang, K.; Page, J.S.; Smith, R.D. Charge competition and the linear dynamic range of detection in electrospray ionization mass spectrometry. J. Am. Soc. Mass Spectrom. 2004, 15, 1416-1423. [CrossRef] [PubMed]

57. Nagy, G.; Veličković, D.; Chu, R.K.; Carrell, A.A.; Weston, D.J.; Ibrahim, Y.M.; Anderton, C.R.; Smith, R.D. Towards resolving the spatial metabolome with unambiguous molecular annotations in complex biological systems by coupling mass spectrometry imaging with structures for lossless ion manipulations. Chem. Commun. 2019, 55, 306-309. [CrossRef]

58. Edelstein, A.D.; Amodaj, N.; Hoover, K.H.; Vale, R.D.; Stuurman, N. Computer Control of Microscopes Using $\mu$ Manager. Curr. Protoc. Mol. Biol. 2010, 92, 14-20. [CrossRef]

59. Schindelin, J.; Arganda-Carreras, I.; Frise, E.; Kaynig, V.; Longair, M.; Pietzsch, T.; Preibisch, S.; Rueden, C.; Saalfeld, S.; Schmid, B.; et al. Fiji: An open-source platform for biological-image analysis. Nat. Methods 2012, 9, 676-682. [CrossRef]

60. Sternberg, S.R. Biomedical Image Processing. IEEE Comput. 1983, 16, 22-34. [CrossRef]

61. Bitter, R.; Mohiuddin, T.; Nawrocki, M. LabVIEW ${ }^{\mathrm{TM}}$ Advanced Programming Techniques; CRC Press: Boca Raton, FL, USA, 2017.

62. Ibrahim, Y.M.; Baker, E.S.; Danielson, W.F.; Norheim, R.V.; Prior, D.C.; Anderson, G.A.; Belov, M.E.; Smith, R.D. Development of a new ion mobility time-of-flight mass spectrometer. Int. J. Mass Spectrom. 2015, 377, 655-662. [CrossRef]

63. Shah, A.R.; Davidson, J.; Monroe, M.E.; Mayampurath, A.M.; Danielson, W.F.; Shi, Y.; Robinson, A.C.; Clowers, B.H.; Belov, M.E.; Anderson, G.A.; et al. An efficient data format for mass spectrometry-based proteomics. J. Am. Soc. Mass Spectrom. 2010, 21, 1784-1788. [CrossRef] [PubMed]

64. Niedermeyer, T.H.J.; Strohalm, M. mMass as a Software Tool for the Annotation of Cyclic Peptide Tandem Mass Spectra. PLoS ONE 2012, 7, e44913. [CrossRef] [PubMed] 